\title{
Cross-departmental Multidisciplinary Approach for the Production and Nutrition Information of a Food Product: A Case Study of the Beer-making for Final Year Practical
}

\author{
Elvis Fosso-Kankeu, Frikkie Conradie, Tertia van Zyl, Franco van de Venter and Martinus Nel
}

\begin{abstract}
As part of the practical of the module Biotechnology II (BIOT411); the final year students of the School of Chemical Engineering have to brew a beer of their choice based on the ingredients available. For the first time this year, it was considered that a specific graduate attribute (GA) would be evaluated in this module namely GA8c which is among the assessable outcomes indicative of a particular competence of a graduate. This GA is expressly considered to encourage the exposure of a student to a multidisciplinary environment where he/she can co-orporate with students from other disciplines. In the BIOT411 practical, a collaboration was established between fourth-year engineering students and fourth-year dietitian students. They had to complement their expertise in beer brewing vs nutritional values and hygienic practices, respectively. This paper, therefore, reports on the development of such collaboration in the context of the Covid-19 pandemic, which imposed adaptation of adequate communication channeling. A survey carried out to determine BIOT411 students' perception revealed that more than $80 \%$ of the students found the benefits of the multidisciplinary approach were covered during the practical; however, they also recognized that restriction measures due to Covid-19 pandemic, limited to some extent the interaction between them and their dietitian colleagues.
\end{abstract}

Keywords - BIOT411 practical, Beer brewing, Multidisciplinary approach, Covid-19.

\section{INTRODUCTION}

The module Biotechnology II is part of the curriculum of the final year (BEng) students in the School of Chemical Engineering in the Faculty of Engineering at the North-West University, South Africa. The module is developed around the concepts of the application of chemical engineering principles to biological systems $[1,2]$. Three main parts are considered to

Manuscript received September 15, 2020.

E Fosso-Kankeu is with the Water Pollution Monitoring and Remediation Initiatives Research Group, School of Chemical and Minerals Engineering, North-West University, South Africa

F Conradie, F van de Venter and M Nel are with the School of Chemical and Minerals Engineering, North-West University, South Africa

T van Zyl is with the Nutrition Department, North-West University, South Africa elaborate on the above concepts, and these include: Basic biological concepts, engineering principles for bioprocesses, and the applications to special systems. It is therefore in this logic that as part of their practical activities, the students have to be exposed to the fermentation process as they produce a beer of their choice under the supervision of a teaching assistant. Beer is the most popular alcoholic beverage that is essentially produced through the fermentation of sugars by yeast [3, 4]. During beer brewing, the main carbohydrate namely starch, is broken down into fermentable sugars such as glucose and maltose by enzymes inherent to the malt at a controlled temperature. The beer's aroma and bitterness are ensured by adding hop at boiling temperature; to provide suitable conditions for the yeast to ferment sugars, a heat exchange system is used to reduce the temperature at an optimum value for the performance of yeast. The overall experiment is carried out using the traditional brewing method in a batch reactor at a controlled temperature. Saccharomyces cerevisiae is the fermenter often used for the production of alcohol. The brewing process is also an ideal breeding ground for undesired bacteria since the wort is rich in nutrients [5]. Special care must therefore be considered during beer brewing to avoid microbial contamination of the beer. Given the importance of sterilization or sanitation, hazard analysis and critical control points (HACCP) verification procedures must be implemented during the brewing process; such expertise is not covered in the scope of Biotechnology II, hence requiring adequate collaboration to minimize the risk of microbial contamination of the beer. Some disciplines such as Nutrition and Dietetics address issues of human nutrition and food safety to mitigate the risks of foodborne illnesses.

Dietitians are trained to better understand the science of food and nutrition. They can therefore be considered as good advisors with regard to the nutritional benefit of food and are in position to inform about the suitability of the quantity or quality of food for a given individual depending of the health status. The collaboration between engineering and dietitian students is therefore expected to be a good match for the beer brewing practical.

For Biotechnology II practical to be carried out in a way that will ensure not only the production of beer according to specifications, but a safer production of the beer and an 
understanding of its nutritional value, it was therefore decided at the end of last year to take a multidisciplinary approach toward the module. A multidisciplinary approach towards teaching has been embraced to a certain extent by the education sector around the world. Given the benefits of the multidisciplinary approach which include, among others, allowing students to reflect on their speciality and discover their own discipline, the link of ideas and concepts by students from various disciplines leading to a rich understanding of complex questions, new opportunities resulting from crossovers between two disciplines, exposure to aspects of real-life applications [6]; it is, therefore, imperative for teaching and learning in higher education to consider the interdisciplinary approach in order to allow individuals from different intellectual backgrounds to collaborate together thus, to combine their expertise. In South Africa, the professional body regulating the standard in the engineering curriculum, name the Engineering Council of South Africa (ECSA) has long promoted such approach which is an assessable outcome and recognized as graduate attribute $8 \mathrm{C}$ to be considered during the evaluation of the competence of BEng students in the School of Chemical Engineering at the North-West University (NWU).

\section{Methodology}

\section{A. Planning of collaboration}

The need to collaborate brought staff from the school of chemical and minerals engineering, and staff from the nutrition department together to discuss the modalities for the collaboration. Once a brief background about the Biotechnology II Practical was presented by the responsible of the module, supported by video of beer brewing process recorded by the previous promotion; the colleagues from the nutrition department found the opportunities to suggest how they could contribute their expertise in aspect such food safety to improve students training and betterment of the whole process. The availability of students and sharing of lab facilities were then discussed, and it was agreed to invite all the students (BEng and Honours) from the two departments during a joint meeting. During the follow-up meeting, the students were then briefed about the principles of the practical and expectations during collaborations, and they were allowed to form groups.

\section{B. Constitution of various groups}

The BEng students who had Biotechnology II as a module were asked to form groups of a maximum of six students to carry out the experimental work; then groups of three each created by the dietitian students had to decide which group of engineers to join. Students were given the opportunity to plan for their collaboration strategies, and the lecturer hosting Biotechnology II, together with the practical demonstrators, advised the students about the availability of ingredients and timetable for beer brewing.

\section{Group work strategies}

According to the multidisciplinary approach, each group from the respective department had to bring their expertise together in order to ensure that the beer brewing was an overall success. The engineers had to conceive a recipe and develop a protocol for the beer brewing while their counterparts from the nutrition department had to advise about the safety measures to be followed to avoid contamination of beer and minimize the risk of accident during brewing. Due to the outbreak of the Covid-19 pandemic, the students did not finally work in the lab, and were given the assignment to write a beer brewing report; their first task was to determine the extraction efficiency and beer specifications given alcohol by volume $(\mathrm{ABV})$ values recorded for the duration of a week by the previous promotion of students. The engineers were the main leaders in aspects related to the fermentation process, while the dieticians were the experts when determining sterilization or sanitation measures, nutritional values and potential toxicity of beer. In the context of lockdown due to Covid-19 pandemic, the students could not meet physically and had to find a way to use social media to their advantage. Each of the four groups mainly used instant messaging services for communication. They each created a chat group including all the members of the group, but practical mentors were also part of the chat groups to monitor the communication. Students also spontaneously made calls or sent emails depending of the matter to discuss and accessibility of the mean of communication.

\section{Evaluation of students' perception}

After submission of their reports, students were asked about their perception regarding several aspects that could have affected the multidisciplinary approach and the Covid-19 pandemic. A rating scale (Disagree, Not sure, Agree and Strongly agree) was used to comparatively present students feedback. Tables 1 and 2 below show the parameters considered to evaluate the students' perception of the multidisciplinary approach on their learning during the beer brewing practical.

TABLE I: IMPACT OF MULTIDISCIPLINARY APPROACH ON LEARNING ABILITY

\begin{tabular}{|c|c|c|c|c|}
\hline Parameters & $\begin{array}{l}\text { Do not } \\
\text { agree }\end{array}$ & $\begin{array}{l}\text { Not } \\
\text { sure }\end{array}$ & Agree & $\begin{array}{l}\text { Strongly } \\
\text { agree }\end{array}$ \\
\hline $\begin{array}{l}\text { Helped me realize the particularity } \\
\text { of my speciality } \\
\text { Helped me understand what the } \\
\text { other students are doing }\end{array}$ & & & & \\
\hline $\begin{array}{l}\text { Made me lose focus } \\
\text { Created fights with students from } \\
\text { other disciplines } \\
\text { Helped me identify new } \\
\text { opportunities } \\
\text { Helped me establish the real-life } \\
\text { application of the practical }\end{array}$ & & & & \\
\hline Improved my communication skills & & & & \\
\hline Helped me find a new friend(s) & & & & \\
\hline
\end{tabular}


TABLE II: IMPACT OF COVID-19 ON PRACTICAL ACTIVITIES

\begin{tabular}{|c|c|c|c|c|}
\hline Parameters & $\begin{array}{l}\text { Do not } \\
\text { agree }\end{array}$ & $\begin{array}{l}\text { Not } \\
\text { sure }\end{array}$ & Agree & $\begin{array}{c}\text { Strongly } \\
\text { agree }\end{array}$ \\
\hline $\begin{array}{l}\text { The reason why I cannot brew beer by } \\
\text { myself }\end{array}$ & & & & \\
\hline $\begin{array}{l}\text { Caused more misunderstanding with } \\
\text { colleagues than if there were physical } \\
\text { meetings }\end{array}$ & & & & \\
\hline $\begin{array}{l}\text { Impacted negatively on the quality of our } \\
\text { report }\end{array}$ & & & & \\
\hline $\begin{array}{l}\text { Prevented me from acquiring all the } \\
\text { benefits of the multidisciplinary approach }\end{array}$ & & & & \\
\hline $\begin{array}{l}\text { Allowed me to explore other avenues of } \\
\text { communication }\end{array}$ & & & & \\
\hline $\begin{array}{l}\text { Allowed me to save time by using social } \\
\text { media for meetings }\end{array}$ & & & & \\
\hline $\begin{array}{l}\text { Working with colleagues from a distance } \\
\text { was a great experience }\end{array}$ & & & & \\
\hline
\end{tabular}

\section{RESULTS AND DISCUSSION}

\section{A. Assignments and strategies adopted by students}

Once the mixed groups of engineering and dietetics students were established, students decided to meet randomly to discuss the practical and the lab work. Eventually, only one group managed to work in the lab. The lab work consisted first to sterilize all the equipment, production of wort (extracted sugar from ground malt), boiling and addition of hops (responsible for aroma and bitterness), cooling, aeration, and yeast pitching, fermentation, the addition of sugar (for carbonation), bottling and capping, and clean-up. Due to the outbreak of the new corona virus (Covid-19); the other groups could not access the lab, and it was then decided to have a virtual practical; the lecturer then sent a video of beer production (involving all the steps mentioned above) by the students of the previous promotion and alcohol by volume percentages (\% ABV) data recorded during seven days fermentation. The students were then asked to consider the type of ingredients and the amount suggested for their kind of beer to determine the corresponding parameters necessary to assess their beer specifications. As for safety measures during the lockdown, all NWU campuses were closed, and students were requested by the university to vacate their residences. Hence almost all the students decided to travel back home. Given that it was no longer possible to meet physically, students decided to make use of their cell phones for most of the communications (calls, instant messaging and emails). Through such platforms, engineers could thus exchange ideas among themselves and with dietitian students to solve the problems related to the practical and contribute to report writing.

\section{B. Achievement of multidisciplinary targets}

It was the first time for the engineering students to work with students from other disciplines, and they expressed their perceptions during a survey. Key important aspects regarding the achievement of multidisciplinary approaches such as the discovery of their own discipline, link of ideas and concepts by students from various disciplines, and exposure to aspects of real-life applications were tested. According to Fig. 1, a significant number (83.3\%) of engineering students agreed that working with dietitian students helped them realize the particularity of their discipline, of this percentage, $33.3 \%$ had a strong feeling about the perception. Engineering students also agreed in a majority (88.9\%) that the collaboration helps them establish the real-life application of the practical. In comparison, $77.8 \%$ of engineering students acknowledged that they became aware of what the dietetic discipline was about by exchanging ideas with dietitian students, which also allowed them to improve their communication skills $(72.2 \%)$. These significant numbers were very impressive given that it was the first time that the students work together. We also noticed that for almost all the students (94.4\%), this was a smooth interaction and some $(22.2 \%)$ managed to find new friends although it was distanced communication.

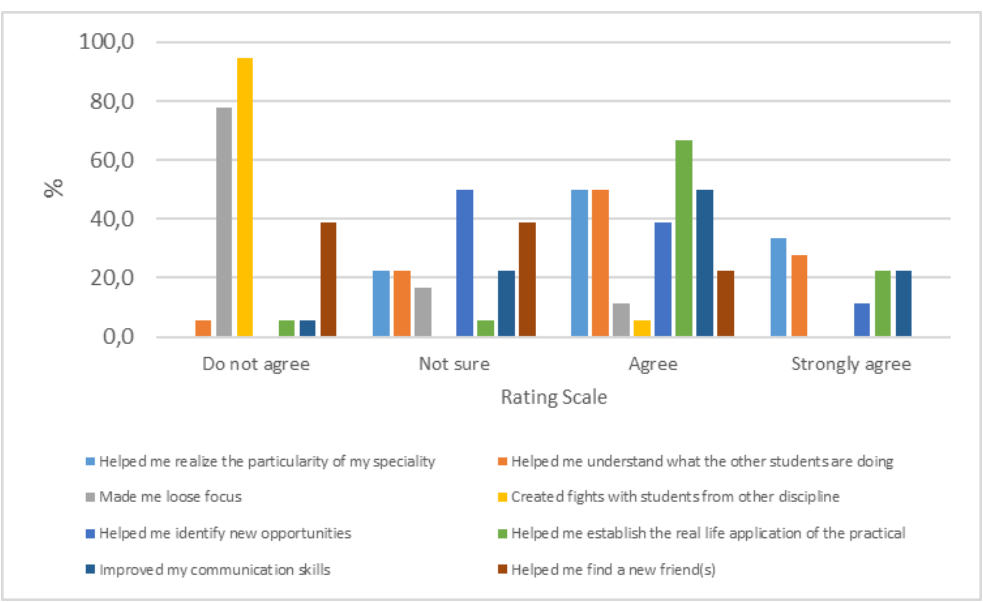

Fig. 1. Results of the survey for interdisciplinary achievements.

\section{Impact of Covid-19}

The Covid-19 outbreak affected the teaching delivery methods as well as the learning strategy. To better understand to what extent the Covid-19 impacted on the multidisciplinary approach considered for BIOT411 practical, a survey was carried out. According to results shown in Fig. 2, most of the students $(66.7 \%)$ believed that the lockdown due to Covid-19 was the reason why they could not brew beer by themselves, given that during the lockdown they could not have access to the lab and practical was done online. The situation also affected students' abilities to acquire all the benefits of the multidisciplinary approach as well as the quality of their report as approved by dominant fractions of $83.4 \%$ and $55.5 \%$ of students, respectively. Engineering students, however, found that the positive aspect of the situation was to be able to explore other avenues of communication (66.6\%) and save time while using social media for meetings (50\%). Overall they did not find the lockdown situation forcing them to work from a distance with their colleagues as a pleasant experience (55.6\%). 


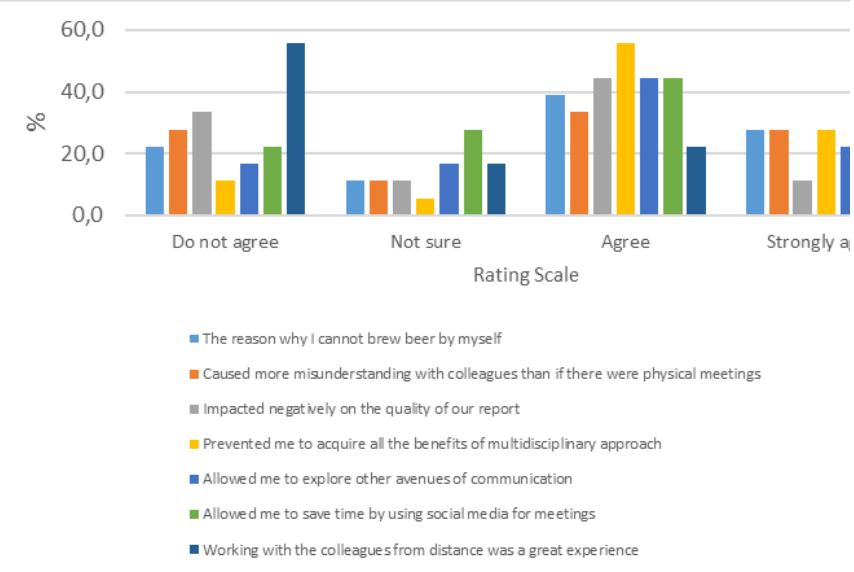

Fig. 2. Results of the survey regarding the impact of Covid-19 on the learning experience.

\section{CONCLUSION}

The aim of the study was to evaluate if the incorporation of the multidisciplinary approach to the BIOT411 practical was achieved based on the parameters previously reported as important indices. It was found that the engineering students approved in the majority that they were able to exchange ideas with their dietitian colleagues to solve complex problems, they discovered more about their own discipline, and managed to establish the real-life application of the practical as they collaborated with dietitian students. The lockdown due Covid-19 outbreak limited the interactions between the students and affected the collaboration. These findings allow to believe that, there is an undeniable potential in collaborating with other disciplines to improve the skill and competence of graduates who exit the school of chemical engineering.

\section{REFERENCES}

[1] Fosso-Kankeu E. 2017. Implementation of active learning strategies based on continuous evaluation and research approach to enhance engineering students performances. $9^{\text {th }}$ Int'l Conference on Advances in Science, Engineering, Technology \& Waste Management (ASETWM-17). 27-28 November 2017, Parys, South Africa. Editors: F. Waanders, E. Fosso-Kankeu, B. Topcuoglu, M. Plaisent, Y. Thaweesak. ISBN: 978-81-934174-6-1. Pp. 326-328.

[2] Fosso-Kankeu E. 2019. Reflective practice in teaching: Assessing suitable strategies for reflective practice in large classes. Editors: Elvis Fosso-Kankeu, Frans Waansders, Hemant Kumar Bulsara. $17^{\text {th }}$ Johannesburg International Conference on Science, Engineering, Technology and Waste Management (SETWM-19) Nov. 18-19, 2019 Johannesburg (South Africa). ISBN-978-81-943403-0-0. Vol. II. Pp 171-173.

[3] Elshani A. \& Kongoli R. 2013. Use of enzymes in the beer production. International Journal of Ecosystems and Ecology Sciences. 3(1): 151-155.

[4] Spitaels F., Wieme A.D., Janssens M., Aerts M., Daniel H-M., Van Landschoot A., et al. 2014. The microbial diversity of traditional spontaneously fermented Lambic Beer. PLos ONE. 9(4): 95384. https://doi.org/10.1371/journal.pone.0095384.

[5] Soupez J-B.R.G. 2016. An interdisciplinary approach to education: case study of an academic exchange. Education \& Professional Development of Engineers in the Maritime Industry, 20-21 September 2016, Singapore.

[6] [4] Malomo O., Ogunmoyela O.A.B., Oluwajoba \& Adekoyeni O.O. 2012. Effect of enzymes on the quality of beer/wort developed from proportions of sorghum adjuncts. http://file.scirp.org/pdf/AiM20120400006_93000799.pdf Date of access: 13 May 2016. 